\title{
PUISI INDONESIA LOMBOK: PERLAWANAN TERHADAP HEGEMONI TUAN GURU
}

\author{
Dharma Satrya HD. \\ dharmasatryahd@gmail.com \\ Universitas Gadjah Mada J1 Nusantara 1, Bulaksumur Yogyakarta
}

\begin{abstract}
This paper discusses Indoesian Lombok poem as a form of resistance toward Tuan Guru (master teacher) hegemony in Lombok. In 2000s, Tuan Guru achieved hegemonic position in Lombok. This paper uses the Gramsci hegemony theory because literary work is assumed to have hegemonic power. The result shows that the conception of Islam is formed in the story of Dewi Rengganis which tells the mixture of Arabic and Lombok Islam. Arabic Islam shows the aspects of form and Lombok Islam shows the substance. Tuan Guru comes with an orthodox Arabic discourse. The poem cleverly chooses the teacher as one way to make the public believe that the ideal teacher is Tuan Guru whose knowledge goes to the prophet. The concept was strengthened through the institutions of Nahdlatul Wathan and Pondok Pesantren. This pesantren boarding school education institution has made the hegemonic position of Tuan Guru last until now. Tuan Guru's hegemony reached its peak when the customs of shoving could be standardized into Islamic law. This pesantren boarding school education institution has made the hegemonic position of Tuan Guru last until now. Tuan Guru's hegemony reached its peak when the customs of sorong serah were standardized into Islamic law. It was in this context that Indonesian Lombok poetry was present to put up a fight against the discourse Tuan Guru. Finally, The poetry sorong serah, nyongkolan and pembayun elevated the discourse of tradition in discursive formation about Lombok.
\end{abstract}

Keywords: hegemony, Tuan Guru, song, Indonesian poem, resistance, tradition

\begin{abstract}
Abstrak: Tulisan ini membahas puisi Indonesia Lombok sebagai bentuk perlawanan terhadap hegemoni Tuan Guru di Lombok. Tahun 2000an, Tuan Guru mencapai posisi yang hegemonik di Lombok. Tulisan ini menggunakan teori hegemoni Gramsci karena karya sastra diasumsikan mempunyai kekuatan hegemonik. Hasil penelitian menunjukkan Lombok diidentitaskan sebagai Islam. Konsepsi mengenai Islam dibentuk melalui cerita Dewi Rengganis dan teks lagu memilih guru. Dewi Rengganis menunjukkan percampuran Islam Arab dan Lombok. Islam Arab menunjukkan aspek bentuk dan Islam Lombok menunjukkan substansi. Tuan guru mengangkat wacana Islam Arab, yang ortodoks. Lagu pandai memilih guru adalah salah satu alat untuk membuat masyarakat percaya bahwa guru yang ideal adalah Tuan Guru, yang ilmunya bersambung sampai nabi. Konsep itu diperkuat melalui institusi Nahdlatul Wathan dan Pondok Pesantren. Lembaga pendidikan pondok pesantren inilah yang membuat
\end{abstract}


posisi hegemonik Tuan Guru bertahan sampai sekarang. Hegemoni Tuan Guru mencapai puncaknya ketika adat sorong serah mampu distandardisasi ke dalam hukum Islam. Dalam konteks itulah puisi Indonesia Lombok hadir untuk melakukan perlawanan terhadap wacana Tuan Guru. Puisi sorong serah, nyongkolan dan pembayun mengangkat wacana tradisi dalam formasi diskursif mengenai Lombok.

Kata kunci: hegemoni, Tuan Guru, teks lagu, puisi Indonesia, perlawanan, tradisi

\section{PENDAHULUAN}

Masyarakat Sasak Lombok di dalam sejarah asal-usulnya didominasi oleh bangsawan (SatryaHD \& Muttaqin, 2018). Namun, sejak era reformasi di Indonesia, posisi bangsawan dalam struktur masyarakat Sasak mengalami pergeseran. Bangsawan, yang awalnya menempati posisi dominan dalam produksi budaya Sasak, mengangkat Lombok sebagai

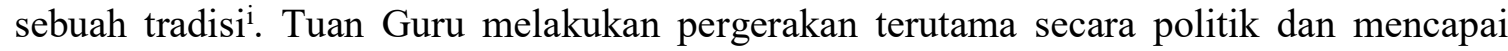
kemenangan pada tahun 2008 (Kingsley, 2011). Tuan guru menempati posisi sebagai gubernur Nusa Tenggara Barat. Tuan Guru memenangkan hati masyarakat Sasak Lombok. Persoalannya, bagaimana Tuan Guru mampu menguasai atau merebut hati masyarakat Sasak Lombok, dengan cara apa dan melalui apa Tuan Guru menggeser posisi bangsawan. Penelitian ini berusaha menjawab persoalan tersebut.

Penelitian mengenai Tuan Guru sudah banyak dilakukan, namun penelitian yang fokus pada hegemoni tuan guru dan counter hegemoni belum ada. Tuan Guru dan ajaran Islamnya diposisikan sebagai sebuah kesempurnaan, kebenaran (Asnawi, 2005). Tuan guru dan ajaran Islamnya dianggap sebagai sesuatu yang baru yang datang dari luar (Zaelani, 2005). Fadjri (2015) justru melihat ajaran Islam sebagai sesuatu yang sudah ada sebelum ajaran itu dibawa oleh mubalig dari Jawa dan Makassar. Artinya, masyarakat Sasak secara ontologis adalah Islam yang dibuktikan dengan syahadat dalam dialek Sasak rahasia (Fadjri, 2015). Temuan Fadjri membantah semua hasil penelitian yang menggunakan perspektif kolonial. Dalam perspektif kolonial masyarakat Sasak asli adalah penganut ajaran boda (Budiwanti, 2000; Harnish, 1993; Hobart, 1983; Jamaludin, 2011; Zaelani, 2005). Fadli (2016) melihat Tuan Guru sebagai ulama yang jaringan keilmuannya meluas sampai ke Harmain. Penelitian mengenai Tuan Guru belum mengeksplorasi posisi hegemonik Tuan Guru di Lombok.

Untuk melihat bagaimana Tuan Guru mencapai posisi yang hegemonik, penelitian ini menggunakan teori hegemoni Gramsci. Faruk memformulasikan teori hegemoni Gramsci dengan beberapa konsep kunci, yaitu kebudayaan, hegemoni, ideologi, kepercayaan popular, kaum intelektual, dan negara (2012, p. 137). Pertama, Kebudayaan dikonseptualisasikan sebagai kekuatan material. Kedua, hegemoni didefinisikan sebagai kepemimpin moral, bentuk kekuasaan. Ketiga, dalam menjalankan kepemimpinan, antara kelas yang berkuasa disatukan melalui kepercayaan-kepercayaan popular. Kepercayaan popular ini mempengaruhi cara memandang dunia. Menurut Faruk, ada tiga cara penyebaran kepercayaan itu, yaitu melalui bahasa, common sense, dan folklore (2012, p. 144). Bahasa digunakan untuk mempengaruhi konsepsi tentang dunia. Common sense dipahami sebagai konsepsi tentang dunia yang paling pervasif dan dimiliki oleh setiap stratum sosial. Common sense itu menciptakan folklore. Common sense menjadi folklorenya filsafat (Faruk, 2012). Menurut Faruk, "hubungan common sense dengan filsafat dijamin oleh politik (2012, p. 147). Common sense sebagai konsepsi tentang dunia atau filsafat tertentu menjadi sebuah gerakan kebudayaan, sebuah ideologi. Ideologi harus disebarkan untuk mencapai hegemoni total. Penyebaran ideologi menggunakan lembaga-lembaga sosial, misalnya pendidikan. Di 
sinilah kaum intelektual berperan penting dalam penyebaran ideologi. Wilayah kesetujuan tempat ideologi disebar itu disebut dengan dunia masyarakat sipil. Dengan beberapa konsep tersebut, sastra (Indonesia) Lombok diasumsikan sebagai kekuatan hegemonik yang menguasai masyarakat Sasak-Lombok. Kekuasaan bangsawan di Lombok dijalankan melalui sastra. Dengan demikian, sastra dipahami sebagai sebuah ideologi. Ideologi adalah sistem representasi yang melaluinya subjek diinterpelasi (Procter, 2004, p. 45). Karena ideologi adalah sistem representasi maka ideologi mempunyai karakter semiotik. Berdasarkan formulasi teori di atas, penelitian ini bertujuan untuk menjelaskan peran sastra sebagai alat hegemoni Tuan Guru dan menjelaskan posisi sastra (puisi) dalam memberikan perlawanan terhadap wacana yang hegemonik mengenai Lombok.

\section{METODE}

Penelitian ini adalah penelitian wacana. Penelitian ini mengasumsikan sastra sebagai sebuah wacana. Oleh karena itu, objek penelitian adalah wacana. Wacana yang dijadikan objek penelitian adalah wacana akademik dan wacana sastra. Wacana akademik yang dijadikan objek adalah wacana mengenai Tuan Guru dan Islam di Lombok. Wacana sastra yang dimakasud adalah wacana mengenai Lombok di dalam sastra. Penelitian mengenai Lombok dan puisi Indonesia mengenai Lombok adalah data dalam penelitian ini. Selain itu, puisi Indonesia Lombok adalah data dalam penelitian ini. Puisi yang dimaksudkan adalah sorong serah, pembayun, dan nyongkol. Data itu diperoleh melalui studi pustaka dan pengalaman peneliti sebagai orang Lombok terutama data teks lagu memilih guru. Analisis data, pertama, dilakukan dengan analisis wacana kontemporer yang berbeda dengan analisis wacana model Foucaultdian. Analisis data tahap pertama adalah analisis wacana sastra mengenai Lombok, khususnya Tuan Guru dan Islam. Kedua, analisis genealogi Islam dan Tuan Guru. Ketiga, analisis lagu sebagai sebuah praktik diskursif. Keempat, analisis posisi puisi dalam merespon dominasi Tuan Guru dan Islam. Kelima, analisis puisi dalam membuat wacana tandingan mengenai Tuan Guru dan Islam.

\section{Cerita Dewi Rengganis sebagai Alat Hegemoni Wacana Islam Arab}

Di dalam cerita Dewi Rengganis, masyarakat Sasak menggambarkam bagaimana hubungan Sasak dengan Mekah. Dewi Rengganis terbang ke Mekah untuk mengambil madu bunga seperti halnya dengan orang Sasak yang pergi Mekah untuk belajar ilmu Islam (Hilmiyatun \& SatryaHD, 2015, p. 465). Mekah menjadi satu legitimasi keilmuan Islam bagi orang Sasak (Fahrurrozi, 2018, p. 6). Tanpa ke Mekah, pergi berhaji, seseorang tidak dapat disebut sebagai Tuan Guru dan tanpa menjadi guru disebuah pondok pesantren ia juga tidak disebut tuan guru (Jamaludin, 2011).

Apa yang terjadi di Mekah setelah Dewi Rengganis sampai di sana? Raden Repatmaja, anak raja negeri Jayangrana, jatuh cinta kepada Dewi Rengganis. Tetapi, Dewi Rengganis tidak menerima cinta Raden Repatmaja. Mekah mejadi dunia yang ideal bagi Lombok, namun justru orang Sasak enggan untuk bersatu dengan Mekah. Kalaupun pada akhinya orang Sasak mengambil ajaran Islam Mekah dan mengajarkannya kepada masyarakat Sasak. Apakah masyarakat Sasak menerima sepenuhnya ajaran Islam itu? Tentu saja, ajaran itu tidak sepenuhnya diterima. Karena pada akhirnya Tuan Guru bernegosiasi dengan kepercayaan lokal Sasak. Negosiasi itu dapat dilihat di dalam upaya Dewi Rengganis untuk menyatukan Raden Repat Maja dengan Dewi Kadarmanik, sahabat dekatnya. Artinya, harus ada jembatan 
antara Lombok dan Mekah. Yang menyatukan yang jauh dan dekat adalah kadarmanik, kadar dari apa yang apa yang dimiliki, yaitu kemampuan memahami antara bunga dan sarinya, antara bentuk dan isi. Dengan kalimat lain, Mekah memiliki bentuk Islam dan Lombok memiliki substansinya, sari bunganya. Itulah alasan Dewi Rengganis ke Mekah, bukan untuk mengambil bunga, tetapi untuk mengambil sarinya. Islam dengan demikian adalah soal sari bunga, bukan bunga itu sendiri. Namun apakah bisa, saripati bunga tanpa bunga?

\section{Tuan Guru dan Islam yang Menubuh}

Islam di Lombok menubuh di dalam institusi Tuan Guru. Jamaludin (2011) sebagai ilmuan dalam bidang kajian Islam merayakan keberadaan Tuan Guru dalam disertasinya tentang sejarah sosial Islam di Lombok. Tuan guru menunjukkan eksistensinya sejak abad 18. Tuan guru membawa misi menyempurnakan ajaran Islam yang masih sinkretik di Lombok. Dalam misi demikian, Tuan Guru membentuk pondok pesantren yang melaluinya pemurinian ajaran Islam dilakukan (Nahdi, 2012). Setelah belajar ilmu agama di Haramain, Tuan Guru membuat forum diskusi yang kemudian berkembang menjadi institusi pendidikan non formal yang disebut sebagai pondok pesantren. Semua Tuan Guru mempunyai pondok pesantren. Pondok pesantren beradaptasi menjadi pendidikan formal menjadi madrasah tsyanawiah (MTs) dan madrasah aliah (MA), yang setara dengan sekolah menengah pertama dan menengah atas. Tuan Gru melembagakan semua ajarannya. Tingkat pendidikan itu mempunyai kurikulumnya sendiri yang berdasarkan pada ajaran Islam ortodoks. Hampir di setiap desa didirikan madrasah. Pendirian madrasah tidak hanya dilakukan di desa-desa yang merupakan basis masyarakat penganut Islam waktu lima atau ortodoks, tetapi juga desa-desa yang masih menganut kepercayaan wetu telu (waktu tiga), tradisi. Desa-desa itu, misalnya Bayan, menjadi target dakwah kelompok Islam ortodoks (Budiwanti, 2000). Usaha pendirian madrasah terus dilakukan. Usaha pendirian itu maksimal dilakukan ketika tuan guru mendapat posisi penting dalam politik dengan terpilihnya Tuan Guru Bajang sebagai gubernur Nusa Tenggara Barat selama dua periode, 2008-2018. Bagaimana upayanya membuat sebagian besar masyarakat Sasak percaya dan setuju dengan pandangannya mengenai Islam dan termasuk organisasi keIslaman yang dibentuknya, yang dalam hal ini Nahdlatul Wathan (NW).

\section{Tuan Guru dan Tradisi Keilmuannya}

Tuan Guru dikonseptualisasikan sebagai sebuah gelar keilmuan. Keilmuan Tuan Guru mengenai Islam dianggap sangat mendalam sehingga gelar Tuan Guru (TG) diberikan di depan namanya. Untuk melihat bagaimana Tuan Guru dikonstruksi, lagu memilih guru dapat dijadikan contoh bagaimana Tuan Guru merebut kepercayaana masyarakat Sasak.

Memilih Guru

Pandai-pandai memilih guru taok ngaji

Guru sak tegak kance jujur ikhlas hati

Mengajar bukan karena materi atau kursi

Hanya semata-mata ikhlas karena ilahi

Sa tui jati taok te beguru ngaji

Sak bedoe silsilah ilmu sampai nabi

Marak maulana bapak kiyai Hamzanwadi 
26 | Bahasa dan Seni: Jurnal Bahasa, Sastra, Seni, dan Pengajarannya

Volume 47, Nomor 1, Februari 2019

Guru dan ilmunya bersambung sampai nabi

Kalau hubungan dengan guru terpisah

Jauh magfiroh dan putus barokah

Putus barokah hilang semua muru'a

Walau ulama sedunia mele pesolah

Dosa bande menyangkut barang inak amaq

Bau tehapus siq intigfar banyak-banyak

Dosa lek guru ndek ne bau tekerisak

Dakaq ne tetebus sik sedunia emas perak

Lagu itu diajarkan pada kali pertama seorang anak belajar ngaji, baik dalam sistem pendidikan informal maupun formal di lingungan Nahdlatul Wathan (NW) ${ }^{\mathrm{ii}}$. Masyarakat Sasak yang menjadi bagian dari organisasi Nahdlatul Wathan (NW) menghafal lagu itu dengan baik. Kenapa lagu itu menjadi lagu wajib anak-anak yang belajar ngaji di lingkungan NW?

Lagu itu mengkonstruksi bagaimana masyarakat Sasak memilih guru. Guru yang harus dipiilih menurut lagu itu adalah guru sak tegak kanca jujur ikhlas hati, guru yang jujur dan ikhlas, yang menegakkan ajaran tuhan. Ikhlas dan jujur yang dimaksudkan adalah mengajar bukan karena materi atau kursi. Artinya, mengajar tanpa mengharapkan imbalan uang atau jabatan. Keikhlasan itu diukur dengan apakah mengajar demi kepentingan ekonomi atau tidak. Jika mengajar untuk kepentingan ekonomi maka ia dapat dikatakan tidak jujur, artinya berbohong kepada jamaat. Atau, sang guru sedang menunda sesuatu. Mengajar dengan ikhlas adalah sebuah strategi untuk tujuan yang lebih besar. Tujuan itu adalah mendapatkan kepercayaan masyarakat.

Bait berikutnya memperjelas apa yang diasumsikan sebagai guru. Guru yang sebenarnya dalam konstruksi lagu itu adalah guru yang ilmunya bersambung sampai nabi. Lagu itu secara eksplisit menunjukkan guru yang demikian, yaitu marak maulana bapak kiyai Hamzanwadi. Kiyai Hamzanwadi ialah pendiri organisasi Nahdlatul Wathan, pahlawan nasional Indonesia. Hamzanwadi mempelajari ilmu agama ke Haramain, tempat Islam pertama diturunkan kepada nabi.

Guru yang harus dipilih menurut lagu itu adalah guru yang pernah belajar ilmu agama ke Haramain. Jika tidak pernah belajar ke sana, maka jangan dipilih untuk dijadikan guru. Artinya, jangan memasukkkan anak untuk belajar ngaji ke guru yang ilmunya tidak bersambung sampai nabi. Atau setidaknya, guru yang merupakan murid dari guru-guru ternama yang pernah belajar ke sana.

Bait pertama dan kedua mengkonstruksi makna guru ngaji. Dalam peta konseptual Islam, guru yang baik adalah guru yang belajar ngaji ke asal dari dari agama Islam. Bait kedua dan ketiga menjelaskan implikasi jika melawan atau tidak memilih jenis guru yang disebutkan di atas. Bait kedua guru dihubungkan dengan orang tua. Jika hubungan dengan guru terpisah maka terputuslah barokah. Artinya, ilmu yang diterimanya tidak mendapatkan barokah. Sedangkan kesalahan atau dosa terhadap orang tua (inak amaq) lebih bisa dimaafkan daripada dosa terhadap guru. Kesalahan pada guru tidak bisa dimaafkan kalaupun ditebus dengan sedunia emas perak.

Lagu itu mengkonstruksi kekuasaan (Tuan) Guru. Kekuasaan dalam konteks ini dimiliki oleh Tuan Guru. Kekuasaan Tuan Guru dibentuk melalui wacana kenabian. Guru yang 
berhak menjadi guru ngaji adalah guru yang pernah belajar atau pernah menunaikan ibadah haji ke Mekah. Ilmu yang diperoleh di negara asal Islam tersebut mendapat pengakuan dari masyarakat. Mekah diasumsikan sebagai pusat, sedangkan yang lain adalah pinggiran. Lagu memilih guru dan cerita Dewi Rengganis sama-sama menjadikan Mekah sebagai pusat. Fadli menjelaskan bahwa ulama-ulama Sasak awal abad 17 sudah pergi menuntut ilmu ke Harmain, tempat Islam diurunkan kepada Muhammad (2016, p. 293). Orang-orang yang belajar ilmu agama ke sana membangun jaringan keilmuan yang di kemudian hari melembaga, misalnya perkumpulan alumni Haramain. Fadli menyebutkan beberapa Tuan Guru yang belajar ke Haramain, diantaranya, TGH Umar Batu Timba, TGH Mustofa Sekarbela, TGH Abdul Gafur, TGH Amin Sesela, TGH Mukhtar Sedayu Kediri, TGH Umar Kelayu, dan lain-lain (Fadli, 2016, p. 295). Untuk menyebarkan ajaran Islam yang dipelajarinya di Haramain, para Tuan Guru membuat pesantren yang awalnya adalah sebuah lingkaran diskusi dan di kemudian hari berkembang menjadi lembaga pendidikan. Lembaga pendidikan menjadi alat untuk membentuk cara masyarakat Sasak memandang dunia.

\section{Pembentukan Kepercayaan Masyarakat Sasak di Era Reformasi}

Sejak masa kolonial sampai rezim orde baru, masyarakaat masih dikuasai oleh bangsawan. Kalaupun rezim orde baru tumbang, rezim bangsawan masih bertahan sampai tahun 2004 dengan terpilihnya putra Sasak pertama, Lalu Srinata, sebagai gubernur pertama Nusa Tenggara Barat. Di era reformasi, Lombok mengalami krisis identitas, antara tradisi dan Islam. Kumbara (2008) melihat adanya kontestasi dalam mendefinisikan identitas orang Sasak. Identitas dikonstruksi berdasarkan kepentingan kekuasaan (Kumbara, 2008). Pada tahun 2004, produksi budaya Sasak adalah budaya yang berhubungan dengan tradisi kebangsawanan, misalnya memperkuat tradisi sorong sera haji krama dan munculnya program kegiatan yang disebut bulan budaya. Setelah lengsernya bangsawan dan digantikan oleh Tuan Guru, maka produksi budaya Sasak berhubungan dengan sesuatu yang Islamis. Seni Musik Lombok yang tidak menunjukkan identitas keIslaman tidak dianggap sebagai musik Lombok (Harnish, 1999, p. 158). Teater tradisi Lombok menunjukkan identitas Islam (Al-Farisi, 2010; Murahim, 2011). Tuan Guru mampu menjaga perdamaian dan keamanan di Lombok (Kingsley, 2011; Kristiansen, 2003; Macdougall, 2007). Segala sesuatu mengalami Islamisasi terutama adat kawin lari. Hukum Islam tidak mengenal proses membawa lari perempuan sebagai tahap awal pernikahan (Yasin, 2008, p. 173). Hukum Islam menawarkan apa yang disebut dengan khitbah atau meminang.

\section{Puisi Indonesia Lombok: Perlawanan terhadap Wacana Tuan Guru}

Posisi hegemonik Tuan Guru di Lombok mendapatkan perlawanan dari masyarakat tradisi, yang memegang kuat adat, misalnya kawin lari atau sorong serah aji krama. Puisi sebagai bentuk perlawanan terahadap Islam ortodoks. Puisi Indonesia Lombok yang muncul tahun 2000an adalah respon terhadap politik identitas yang dilakukan oleh kelompok Tuan Guru. Puisi-puisi yang muncul adalah puisi tentang adat sorong serah aji krama. Puisi-puisi itu muncul dari penyair kelompok bangsawan dan (perwangsa) dengan jamaq. Bangsawan diwakili oleh Anang Zubaidi Soemerep, sedangkan dengan jamaq (orang biasa) diwakili oleh Imam Safwan dan Kiki Sulistyo.

Puisi Sorong Serah (2004) karya Anang Zubaidi merupakan kumpulan puisi pertamanya di bawah asuhan penyair Putu Arya Tirtawirya. Sorong serah merupakan adat yang merepresentasikan kelas bangsawan (Kumbara, 2008), karena hanya para bangsawan yang 
dapat menjalankan adat sorong serah secara ideal. Adat sorong serah diperjuangkan oleh kelompok bangsawan sebagai adat khas Lombok, sebagai identitas etnik Lombok (Kumbara, 2008: 322). Sorong serah merupakan pemberian harga pihak laki-laki kepada perempuan (Yasin, 2008: 277). Sorong Serah adalah proses yang berlangsung ketika seorang sepasang kekasih sudah melalui pernikahan, rebaq pucuk. Proses yang terjadi sebelum sorong serah adalah melaiqang (membawa lari perempuan), nyelabar (memberikan kabar), mesejati (memberikan kepastian), bait wali (mengambil wali perempuan), rebak pucuk (pelaksanaan nikah atau begawe), sorong serah (penyerahan dalam bentuk harga), nyongkol (perayaan penikahan), balik lampak (membalas jejak). Sorong serah dimulai dengan sebuah proses yang disebut penyerahan harga oleh pihak laki-laki. Jika perempuan dari kalangan bangsawan, maka ia diberikan harga $66^{\mathrm{iii}}$, harga yang lebih tinggi dari golongan biasa (jajar karang atau dengan jamaq). Puisi sorong serah ${ }^{i v}$ menggambarakan konsep penyerahan tersebut.

Kini malam telah menyerahkan sepi (1)

ke ranting ranting yang jatuh (2)

maka terbagilah mimpi yang abadi (3)

untukmu (4)

Kenapa malam menyerahkan sepi? Siapa yang dimaksudkan malam? Malam merupakan tanda bagi kondisi gelap karena terbenamnya matahari. Sebagai penanda, malam adalah konsep yang mengacu pada laki-laki. Dalam budaya masyarakat Sasak-Lombok, malam adalah dunia laki-laki, karena hanya laki-laki yang dibiarkan keluar rumah terlebih lagi keluar mengunjungi perempuan di rumahnya. Dalam bahasa Sasak kunjungan ke rumah perempuan dengan maksud menjali hubungan cinta disebut midang.

Baris (1) menunjukkan bahwa laki-lakilah yang melakukan penyerahan kepada pihak perempuan. Penyerahan tersebut adalah sebuah pembayaran karena laki-laki tersebut mengambil perempuan dari orang tuanya untuk dijadikan istri. Pembayaran tersebut mewujud dalam bentuk harga berupa uang yang disepakati. Namun, harga ditentukan oleh posisi keluarga perempuan. Jika perempuannya bangsawan, maka ia akan membayar mahal dan jika perempuan berasal dari kelas dengan jamaq (orang biasa), maka laki-laki akan membayar lebih murah. Baris (2) menunjukkan bahwa penyerahan itu dilakukan kepada ranting-ranting yang jatuh. Ranting sebagai sebuah tanda dimaknai sebagai sebuah bagian dari pohon atau batang utama. Jatuhnya ranting tidaklah karena dijatuhkan oleh seseorang, tetapi karena jatuh dengan sendirinya yang disebabkan oleh angin atau cuaca atau oleh perbuatan manusia. Puisi itu memberikan kesan bahwa ranting itu jatuh dengan sendirinya, jatuh secara alamiah. Dalam kebudayaan Lombok, perempuan tidaklah mendapat posisi yang penting dalam kelurga, karena garis keturunan ditentukan oleh laki-laki, bukan perempuan. Posisi itu menempatkan perempuan sebagai bagian kecil dari sebuah keluarga besar yang tidak sentral dalam penentuan generasi penerus.

Ranting-ranting merupakan personifikasi dari perempuan yang sudah terpisah dari pohon (keluarganya). Artinya, si laki-laki menikahi perempuan yang sudah terpisah dari keluarganya dan atau yang terbuang dari keluarganya. Ada ranting yang jatuh dan ada ranting yang tetap di pohon. Yang jatuh tidak mempunyai kekuatan untuk bertahan, sedangkan yang tetap di pohon mampu bertahan. Jika petandanya adalah bangsawan maka ranting yang jatuh tidak mampu mempertahankan tradisi kebangsawanannya. Jika patandanya adalah orang biasa, maka yang jatuh adalah ranting yang tidak memegang adat atau prinsip keluarga. 
Seorang bangsawan yang bergelar raden ${ }^{v}$ tidak menikah dengan perempuan bangsawan yang setara, yang bergelar denda, maka tingkat kebangsawanannya turun satu level, dari raden ke lalu.

Baris (2) menunjukkan bahwa posisi laki-laki lebih kuat dibandingkan dengan perempuan, artinya hubungan laki-laki dan perempuan tidak setara. Dalam pernikahan yang masyarakatnya masih mempertahankan sistem kasta, kesetaraan menjadi sangat penting dalam pelestarian kelas sosial laki-laki, kebangsawanan. Jika pelestarian kelas sosial lakilaki tidak dipelihara dengan menikahi perempuan yang setara atau pada level yang sama secara kasta, maka hanya mimpi yang abadi terbagi untukmu, baris (3) dan (4). Baris itu menempatkan laki-laki yang menikah tersebut mempunyai mimpi yang abadi. Baris itu menunjukkan sebuah implikasi, jika laki-aki menikah dengan perempuan yang terpisah atau terbuang dari keluarganya atau tidak setara gelar kebangsawanannya, maka terbagilah mimpi yang abadi. Hal itu terjadi karena kenyataan yang diterima atau yang dialami tidak sesuai dengan yang diharapkan, sehingga hanya mimpi yang menjadi bagiannya, bagian yang harus diterimanya.

Dan sekarang kau kan selalu mendengar (5)

sepi riuh berlenggang di kupingmu (6)

sampai tertidur lelap sekalipun (7)

mimpi itupun setia menyelimutimu (8)

Baris (5) menggambarkan kau (laki-laki) mendapatkan pendengaran, sesuatu yang mengusik ketenangan, karena penyerahan yang ia berikan bukan pada orang yang tepat dalam konteks sistem kasta. Yang ada hanyalah pendengaran tentang sebuah kesalahan dalam memilih. Tinggal sepi riuh yang ia dengar, yang merupakan realitas hidupnya, karena yang nyata adalah apa yang didengar. Hal itu dialaminya sampai tertidur sekalipun (7). Artinya, suara-suara orang lain dan dirinya mengusiknya walaupun dalam keadaan tertidur. Yang tersisa hanyalah mimpi, yang setia menyelimutinya (8). Mimpi tentang kebahagiaan, tentang kehormatan sebagai laki-laki, tentang kehormatan keluarga, tentang kehormatan sebagai bangsawan.

Berharaplah biar malam jadilah gemintang dan (9)

siang yang terlentang jadilah bening (10)

mungkin dengan begitu suatu pertanda (11)

berkahnya sungguh telah menyelinap pada (12)

gumpal hatimu (13)

Baris (9) dan (11) menunjukkan sebuah seruan dan kemungkinan, karena tinggal berharap apakah penikahan itu membawa berkah atau tidak. Bagaimana mengetahui bahwa sesuatu yang dilakukannya membawa berkah ke hati? Jawabannya adalah karena ada yang merekah, bahagia seperti malam jadilah gemintang (9) dan siang yang terlentang jadilah bening (10). Artinya, yang ada hanya kebahagiaan, kesejukan, hati yang penuh keceriaan. Jika ditarik garis dari baris awal sampai akhir dalam puisi itu, maka puisi ini berbicara tentang apakah penyerahan itu membawa berkah? Penyair sendiri tidak mengetahuinya, karena ia melihat dari luar, berjarak. Itulah sebabnya ia memilih kata mungkin dan berharap. Puisi tersebut memposisikan laki-laki yang mempunyai posisi sosial yang tinggi sebagai korban sistem kasta yang masih berlaku dalam budaya Lombok. Laki-laki dengan posisi sosial yang 
30 | Bahasa dan Seni: Jurnal Bahasa, Sastra, Seni, dan Pengajarannya

Volume 47, Nomor 1, Februari 2019

rendah juga mengalami hal yang sama, karena dalam sorong serah ia akan membayar mahal perempuan yang posisi sosialnya lebih tinggi dengan jaminan beberapa are tanah dan sebuah rumah. Namun, jika posisi sosialnya sama maka mereka memperoleh jalan keluar yang cepat dalam menentukan harga yang dibayarkan.

Puisi itu menggambarkan budaya Lombok dalam perspektif kelas bangsawan, karena hanya kelas bangsawan yang masih mempertahankan budaya tersebut. Sorong serah ini menjadi strategi bangsawan untuk memperkuat identitas kebangsawanannya (Kumbara, 2008). Selain itu, lagu atau tembang dijadikan alat oleh bangsawan untuk mempengaruhi cara masyarakat melihat dunia (SatryaHD \& Muttaqin, 2018). Sorong serah merupakan identitas budaya Lombok yang dikontruksi oleh bangsawan (Kumbara, 2008). Namun, kenapa aspek yang disebut ngewacan ${ }^{v i}$ tidak dimunculkan dalam puisi tersebut? Puisi itu tidak menunjukkan pentingnya proses itu. Puisi itu mereduksi sorong serah hanya kedalam konsep penyerahan laki-laki kepada perempuan. Artinya, puisi tersebut sebenarnya berbicara tentang esensi adat sorong serah. Puisi ini menempatkan proses sorong serah sebagai proses yang sudah tidak lagi menjadi sesuatu yang diperjuangkan untuk dipertahankan. Yang penting dalam puisi itu adalah produksi identitas Lombok sebagai masyarakat yang memelihara tradisi, namun menampilkan esensinya. Produksi makna tentang budaya Lombok dalam puisi tersebut berbeda dengan produksi makna yang dilakukan Kiki Sulistyo dalam puisi pembayun (2015). Dalam puisi itu Kiki Sulistyo menekankan bentuk penyerahan.

maka pada hari yang tak terperi datanglah aku (1)

membawa sirih-pinang dalam pinggang (2)

kelon-intim calon pengantin (3)

akan dinikahkan atas tanah dan tanaman (4)

keris dan warangka sehabis ajikrama (5)

dengan kirangan seekor kerbau jantan (6)

yang punuknya seperti gunduk berjurang (7)

empat puluh cambukan di punggung bujang (8)

untuk tiap peluh yang pulang ke badan (9)

ketika melarikan perawan ke rumah persembunyian (10)

sebelum selabar datang ke kampong seberang (11)

aku berjalan paling depan sebab aku membawa kabar (12)

bakal tersiar ke penjuru pasar: dia yang tak pulang (13)

telah terikat benang hasta, benang pengantar pesan (14)

: dia memilih menjadi dauh sirih bagi pinang di pinggan (15)

Baris (2), (4), (5), dan (6) menunjukkan bentuk adat sorong serah. Penyerahan harga kepada perempuan oleh pihak laki seringkali berbentuk tanah, kerbau, atau uang yang ditentukan oleh posisi sosial laki-laki dan perempuan. Semua jenis pembayaran tersebut diserahkan oleh seorang yang disebut pembayun. Pembayun menjadi wakil kedua keluarga. Ada pembayun pemberi dan pembayu penerima. Puisi pembayun di atas disertai dengan proses yang lain, yaitu pada baris (10) dan (11), (12), (13), (14), dan (15) melaiqang (membawa lari) dan nyelabar (memberi kabar). Puisi tersebut memproduksi makna pembayun sebagai bagian yang paling penting dalam adat sorong serah aji krama Lombok. 
Tanpa ada pembayun tidak terjadi proses sorong serah. Dalam puisi sorong serah karya Anang Zubaidi, pembayun tidak begitu penting, karena pembayun adalah simbol kebangsawanan. Posisi pembayun diisi oleh para bangsawan, karena hanya mereka yang bisa menggunakan bahasa Sasak Alus yang merupakan percampuran bahasa Jawa dan Bali (Murcahyanto \& Al-Pansori, 2015). Perbedaan cara melihat konsep tentang sorong serah adalah perbedaan pandangan dalam memahami konsep tersebut. Konsep yang pertama muncul dari kelas bangsawan, sedangkan yang kedua dari kelas jajar karang (orang biasa). Anang Zubaidi adalah seorang djero $^{\text {vii }}$ yang sudah tidak lagi memakai gelar bangsawan tetapi masih masih dianggap bangsawan. Posisinya sebagai seorang dosen di Universitas Mataram mempengaruhi cara berfikirnya. Ia berusaha mereduksi makna. Bentuk-bentuk dalam adat sorong serah menjadi tidak penting dengan cara berfikir demikian. Sedangkan, Kiki Sulistyo sebagai seorang jajar karang justru mementingkan aspek bentuk tersebut, karena tidak semua jajar karang mampu menjalankan adat sorong serah. Pandangan yang berbeda tentang sorong serah tersebut sebenarnya dua pandangan dalam generasi yang berbeda. Djero Anang Zubaidi termasuk generasi tua dan Kiki Sulistyo termasuk generasi muda. Yang tua mementingak esensi, sedangkan yang muda mementingkan bentuk.

Berbeda dengan Anang Zubaidi dan Kiki Sulistyo, Imam Safwan melihat nyongkol sebagai proses yang penting dalam budaya merarik (perkawinan) Sasak-Lombok. Budaya nyongkol diangkat oleh Imam Safwan dalam antologi puisi Langit Seperti Cangkang Telus Bebek (2014).

Sudah terdengar kabar (1)

Gending berkabar (2)

Gemericik gelang dan kembang goyang (3)

Ada yang mengusung payung (4)

Melindungi pengantin (5)

berkain songket baju lambung (6)

Telah terikat tali ikatan (7)

Di kiri lengan (8)

Sudah terdengan kabar (9)

Gending berkabar (10)

Orang-orang memagar desa (11)

Beraneka ragam rupa dan rasa (12)

Menyusun senyum jadi tawa (13)

Juga prasangka (14)

Sudah terdengar (15)

gending berkabar (16)

mengantarkan kesombongan (17)

melalui musik yang bergetar (18)

dan tarian para pengantar (19)

Sudah terdengar (20) 
32 | Bahasa dan Seni: Jurnal Bahasa, Sastra, Seni, dan Pengajarannya

Volume 47, Nomor 1, Februari 2019

Gending berkabar (21)

Menyuarakan peradaban (22)

Pada celana jeans dan kebaya (23)

Pada sepatu pantopel dan ikat kepala (24)

Juga pada cilokaq dan rekenrol (25)

Yang menyatu jadi kecimol (26)

Padahal (27)

Sudah terdengar (28)

lontar berkabar (29)

“ini bukan gending peperangan (30)

Tapi gending persahabatan (31)

Untuk kita saling mengenal (32)

dan menjalin tali persaudaraan" (33)

Sudah terdengar (34)

gending berkabar (35)

menyuarakan kesakitan (36)

budaya yang mulai pudar (37)

Puisi itu menggambarkan proses yang terjadi ketika seorang pengantin mengabarkan kepada masyarakat bahwa dirinya telah menikah. Nyongkol tersebut adalah konsep tentang memberi kabar kepada masyarakat luas bahwa ia telah menikah. Kabar dalam proses nyongkol berbeda dengan kabar dalam proses membawa lari perempuan (melaiqang). Kabar yang disampaikan dalam proses nyelabar adalah kabar bahwa anak perempuannya akan menikah dan ia dibawa lari dari rumahnya untuk menikah. Sedangkan, kabar dalam proses nyongkol adalah kabar sesudah terjadi pernikahan, artinya sudah sah sebagai suami istri. Dalam puisi tersebut Imam Safwan menggambarakan bentuk nyongkol. Dalam pelaksanaan nyongkol tersebut disertai dengan gending serta perlengkapan adat, misalnya berkain songket dan membawa payung. Baris (1) sampai (8) menunjukkan penggambaran fisik proses nyongkolan. Payung, kain songket, baju lambung adalah properti yang harus ada dalam proses tersebut. Baris (11), (12), (13), dan (14) tersebut menunjukkan bagaimana Imam Safwan menggambarkan reaksi masyarakat yang menonton pengantin yang sedang nyongkol. Orang-orang yang menonton berada dipinggir jalan seperti sedang memagari desa dan di antara mereka ada yang senang tertawa dan membangun prasangka terhadap pengantin tersebut. Sementara para pengiring (pengantar) menunjukkan kesombongannya dengan musik dan tarian. Baris (17), (18), (19) menunjukkan kondisi nyongkol yang dipenuhi dengan musik tarian. Kondisi yang mendukung para pengantar untuk bertindak demikian adalah perubahan peradaban dari tradisi ke modern, misalnya menggunakan celana jeans, kebaya, dan sepatu pantopel, Ikat kepala, cilokaq dan rokenrol yang semua itu terlihat dalam musik kecimol.

Baris (22), (23), (24), (25), dan (26) menunjukkan terjadinya percampuran budaya, yaitu Lombok dan Barat. Jeans bukanlah pakaian adat Lombok dan cilokaq dianggap musik khas Lombok. Percampuran musik cilokaq dengan musik modern melahirkan muisk yang disebut 
dengan kecimol (Yudarta \& Pasek, 2017). Dalam konteks pariwisata, musik itu diidentifikasi sebagai musik Lombok kontemporer. Musik cilokaq Lombok adalah musik yang dipengaruhi oleh musik Melayu terutama pada alat musik dan syairnya. Namun, cilokaq sudah bercampur dengan musik Barat terutama penggunaan gitar dan keybord. Bagi masyarakat Sasak, musik cilokaq adalah musik khas Lombok. Jika masyarakat Sasak menerima cilokaq sebagai identitas budayanya, maka ia menerima pengaruh musik lain yang, terutama Melayu. Yang menjadi permasalahan dalam baris (22) sampai (26) adalah munculnya konflik di dalam nyongkol tersebut, karena seringkali diantara para pengiring, orang yang mengiring pengantin laki dan perempuan, bertengkar untuk menunjukkan kelompok pengiring mana yang kuat dan hebat untuk menarik penonton. Dalam penafsiran Imam Safwan, nyongkol tersebut melahirkan konflik antara para pengiring atau penonton. Itulah alasan pada baris (27) sampai (33) Imam Safwan mempertegas fungsi dari nyongkol tersebut, yaitu menjalin tali persaudaraan. Pada baris itu, Imam safwan menekankan fungsi nyongkol tersebut adalah mengabarkan dan sekaligus bentuk persaudaraan yang dibangun oleh dua keluarga besar yang menyatu menjadi satu. Di lain sisi, Imam Safwan menggambarkan bahwa nyongkol tersebut menyuarakan kesakitan dan budaya yang mulai pudar, yaitu pada baris (34) sampai (37). Pada baris (34) sampai (37), Imam Safwan menunjukkan pandangannya tentang budaya Lombok yang mulai pudar. Ia memandang bahwa budaya Lombok sudah mulai didominasi oleh budaya Barat. Hal itu terjadi seiring dengan maksimalisasi Lombok sebagai tujuan wisata.

\section{KESIMPULAN}

Pandangan masyarakat Sasak terhadap Islam terbagi menjadi dua, yaitu Islam bentuk dan Islam substansi. Yang pertama dikenal dengan Islam syariat, sedangkan yang kedua dikenal dengan Islam hakikat. Yang pertama menekankan pelaksanaan syariat Islam, sedangkan yang kedua memadukan yang pertama dengan elemen adat atau tradisi. Dalam konstruksi kolonial yang pertama dikenal dengan Islam ortodoks, sedangkan yang kedua dikenal dengan istilah wetu telu atau heterodoks. Islam ortodoks menubuh dalam institusi sosial dan pendidikan dalam bentuk organisasi sosial dan pendidikan yang disebut dengan organisasi Nahdlatul Wathan dan pondok pesantren. Keduanya mempunyai misi menyempurnakan Islam ke dalam bentuknya yang ideal dalam pengertian Islam Arab. Konsep yang demikian itulah yang membentuk institusi Tuan Guru dan jariangan keilmuannya sampai ke Haramain, tempat Islam diturunkan pertama kali. Sastra dalam bentuk syair dan lagu, terutama lagu memilih guru, sebagai alat hegemoni untuk membuat masyarakat Sasak percaya bahwa guru yang ideal adalah guru yang ilmunya bersambung sampai nabi, yang dalam hal ini adalah Tuan Guru yang belajar ke Haramain. Setelah mendapatkan kepercayaan masyarakat, Tuan Guru memilih jalur politik dengan menjadi gubernur Nusa Tenggara Barat sejak tahun 2008-2018. Produksi kebudayaan terutama dan yang paling menonjol adalah adat perkawinan yang disebut dengan sorong serah haji krama mengalami penyesuaian dengan hukum Islam dan bahkan hukum Islam mulai menggeser tradisi sorong serah. Dalam posisi yang demikian, Tuan Guru mendapatkan perlawanan dari kalangan tradisi. Puisi menjadi alat untuk melakukan perlawanan. Puisi Indonesia Lombok 2000an dan 2010an mengangkat kembali adat sorong serah dan terutama adat nyongkolan dan tradisi ngewacan yang dilakukan oleh seorang pembayun. Anang Zubaidi Soemerep, Kiki Sulistyo, dan Imam Safwan mewakili generasi muda dan tua mengangkat kembali elemen tradisi yang diabaikan oleh discourse Islam waktu lima atau Islam yang diperjuangkan Tuan Guru. Puisi Indonesia Lombok 
34 | Bahasa dan Seni: Jurnal Bahasa, Sastra, Seni, dan Pengajarannya Volume 47, Nomor 1, Februari 2019

dijadikan kekuatan untuk melawan rezim Tuan Guru. Sastra (puisi) melakukan counter hegemoni terhadap wacana Tuan Guru mengenai Lombok.

\section{ENDNOTE}

\footnotetext{
' Analog dengan konsep abangan Geertz

${ }^{\text {ii }} \mathrm{NW}$ merupakan oragnisasi keagamaan berbasis Islam terbesar di Lombok.

iii Harga yang ditentukan sesuai kesepakatan kedua belah pihak. Angka 66 merupakan simbol harga kebangsawanan yang berbeda dengan harga yang bukan bangsawa, dengan jamaq dengan harga 33 .

iv Puisi sorong serah diambil dari kumpulan puisi Sorong Serah (2004) karya Anang Zubaedi.

${ }^{\vee}$ Raden merupakan gelar tertinggi bangsawan Sasak, sedangkan gelar denda untuk perempuan. Di bawah raden ada gelar lalu untuk laki dan baiq untuk perempuan.

${ }^{v i}$ Ngewacan adalah proses yang dalam sorong serah merupakan proses berbalas pantun dalam bahasa Sasak alus yang merupakan percampuran bahasa Jawa dengan bahasa Bali.

vii Djero adalah nama panggilan seorang bangsawan, baik laki-laki maupun perempuan. Namun, di dalam nama bangsawan yang muncul adalah nama baiq untuk perempan dan lalu untuk laki-laki. Nama djero di depan nama anang zubaidi mengindikasikan bahwa ia seorang bangsawan.
}

\section{DAFTAR RUJUKAN}

Al-Farisi, S. (2010). Teater Cepung Lombok (Kajian Tekstual Seni Pertunjukan Lombok). Institut Seni Indonesia Yogyakarta.

Asnawi. (2005). Respons Kultural Masyarakat Sasak terhadap Islam. Ulumuna, IX(1), 1-19. Budiwanti, E. (2000). Islam Sasak: Waktu Telu versus Waktu Lima. Yogyakarta: LKIS.

Fadjri, M. (2015). Mentalitas dan Ideologi dalam Tradisi Historigrafi Sasak Lombok pada Abad XIX-XX. Universitas Gadjah Mada.

Fadli, A. (2016). Intelektualisme Pesantren: Studi Genealogi dan Jaringan Keilmuan Tuan Guru di Lombok. El Hakim, 9 Nomor 2, 287-310.

Fahrurrozi. (2018). Tuan Guru and Social Change in Lombok, Indonesia. Indonesia and the Malay World, O(0), 1-18. https://doi.org/10.1080/13639811.2018.1452487

Faruk. (2012). Pengantar Sosiologi Sastra: dari Strukturalisme Genetik sampai Postmodernisme (kedua). Yogyakarta: Pustaka Pelajar.

Harnish, D. (1993). The Future Meets the Past in the Present: Music and Buddhism in Lombok. Asian Music, 25(1), 29-50.

Harnish, D. (1999). Reviewed Work ( s ): Be Not Afraid to Strike the Gong: The Music of Lombok by Christopher Basile. Asian Music, 30(2), 157-160.

Hilmiyatun, \& SatryaHD, D. (2015). Dewi Rengganis (Kajian Antropologi Sastra LeviStrauss). Education, 10(2), 449-468.

Hobart, M. (1983). Reviewed Work(s): The Spell of the Ancestors an the Power of Mekkah: A Sasak Community in Lombok by Sven Cederroth. Bulletin of the School of Oriental and African Studies, 46(2), 398-399.

Jamaludin. (2011). Sejarah Sosial Islam di Lombok tahun 1740-1935 (Studi Kasus terhadap Tuan Guru).

Kingsley, J. (2011). Pelopor Perdamaian atau Perusak Perdamaian?: Pemilihan Kepala Daerah, Kepemimpinan Agama, dan Proses Perdamaian di Lombok. In A. F. Susanto 
(Ed.), Kegalauan Identitas: Agama, Etnisitas, dan Kewarganegaraan Pada Masa PascaOrde Baru (pp. 97-118). Jakarta: Gramedia.

Kristiansen, S. (2003). Violent Youth Groups in Indonesia: The Cases of Yogyakarta and Nusa Tenggara Barat. Sojourn: Journal of Social Issue in Southeast Asia, 18(1), 110-138.

Kumbara, A. A. N. A. (2008). Konstruksi Identitas Orang Sasak di Lombok Timur, Nusa Tenggara Barat. Humaniora, 23 Nomor 3, 315-326.

Macdougall, J. M. (2007). Criminality and the Political Economy of Security in Lombok. In H. S. Nordholt \& G. van Klinken (Eds.), Renegotiating Boundaries (pp. 281-304). Brill.

Murahim. (2011). Ekspresi Nilai-Nilai Budaya Sasak Kemedi Rudat. Universitas Negeri Malang.

Murcahyanto, H., \& Al-Pansori, M. J. (2015). Leksikon Pembentuk Tingkat Tutur Pada Upacara Adat Sorong Serah Aji Krama di Desa Sakra Kabuaten Lombokn Timur. Selong.

Nahdi, K. (2012). Nahdlatul Wathan dan Peran Modal: Studi Etnografi Historis Modal spiritual dan Sosiokultural. (S. Purnama, Ed.). Yogyakarta: Insyira.

Procter, J. (2004). Stuart Hall. London \& New York: Routletge.

Safwan, I. (2014). Langit Seperti Cangkang Telur Bebek. Mataram: Akar Pohon.

SatryaHD, D., \& Muttaqin, Z. (2018). Representasi Bangsawan Sasak dalam Teks Angin Alus Masyarakat Sasak. Litera, 17(1), 107-119.

Soemerep, D. A. Z. (2004). Sorong Serah, Kumpulan Puisi. (P. A. Tirtawirya, Ed.). Mataram: Asta Perdana.

Sulistyo, K. (2015). Penangkar Bekisar. Bandung: Nuansa Cendikia.

Yasin, N. (2008). Hukum Perkawinan Islam Sasak. Malang: UIN Malang Press.

Yudarta, I. G., \& Pasek, I. N. (2017). Kecimol Music as Cultural Identification of Sasak Ethnic. Art and Culture, 32 Nomor 3, 314-318.

Zaelani, Kamarudin. (2005). Dialektika Islam dengan Varian Kultur Lokal dalam Pola Keberagaman Masyarakat Sasak. Ulumuna, IX(1), 48-70. 